University of Wollongong

Research Online

Faculty of Social Sciences - Papers (Archive) Faculty of Arts, Social Sciences \& Humanities

2015

Movement of garden plants from market to bushland: gardeners' plant procurement and garden-related behaviour

Ren $\mathrm{Hu}$

University of Wollongong, rh407@uowmail.edu.au

Nicholas J. Gill

University of Wollongong, ngill@uow.edu.au

Follow this and additional works at: https://ro.uow.edu.au/sspapers

Part of the Education Commons, and the Social and Behavioral Sciences Commons

Research Online is the open access institutional repository for the University of Wollongong. For further information contact the UOW Library: research-pubs@uow.edu.au 


\title{
Movement of garden plants from market to bushland: gardeners' plant procurement and garden-related behaviour
}

\author{
Abstract \\ In Australia, the largest importer of exotic plant species is the gardening industry, and most major \\ environmental weeds originally derive from domestic gardens or nurseries. To provide strategies for weed \\ management, this study aims to clarify two key points on the pathway along which garden plants flow \\ from the market to the natural environment with the help of human activities. These are local residents' \\ procurement of garden plants, and local residents' garden-related behaviour (e.g. leaving organic \\ materials in reserves). We draw on a survey (382 respondents) among Wollongong (New South Wales, \\ Australia) residents whose property has at least one boundary adjacent to bushland. Frequency analysis \\ and ordinal regression were used. The results indicated that most respondents obtained garden plants, \\ and relevant information, from nurseries but perceived that there was insufficient plant origin information \\ (that is, whether introduced from abroad, native to Australia or local to the Illawarra) to help them make \\ choices. It also indicated that a minority of respondents frequently left organic materials (such as lawn \\ clippings) in reserves neighbouring their garden, and many of these respondents saw some benefits in \\ doing so. This study confirms the significant role of nurseries in gardeners' plant choice, and raises \\ questions about the significance of dumping garden waste.
}

\section{Keywords}

related, procurement, plant, behaviour, gardeners, movement, bushland, market, plants, garden

\section{Disciplines}

Education | Social and Behavioral Sciences

\section{Publication Details}

Hu, R. \& Gill, N. (2015). Movement of garden plants from market to bushland: gardeners' plant procurement and garden-related behaviour. Geographical Research, 53 (2), 134-144. 


\title{
Movement of Garden Plants from Market to Bushland: Gardeners' Plant
}

\section{Procurement and Garden-related Behaviour}

\begin{abstract}
In Australia, the largest importer of exotic plant species is the gardening industry, and most major environmental weeds originally derive from domestic gardens or nurseries.
\end{abstract} To provide strategies for weed management, this study aims to clarify two key points on the pathway along which garden plants flow from the market to the natural environment with the help of human activities. These are local residents' procurement of garden plants, and local residents' garden-related behaviour (e.g. leaving organic materials in reserves). We draw on a survey (382 respondents) among Wollongong (New South Wales, Australia) residents whose property has at least one boundary adjacent to bushland. Frequency analysis and ordinal regression were used. The results indicated that most respondents obtained garden plants, and relevant information, from nurseries but perceived that there was insufficient plant origin information (that is, whether introduced from abroad, native to Australia or local to the Illawarra) to help them make choices. It also indicated that a minority of respondents frequently left organic materials (such as lawn clippings) in reserves neighbouring their garden, and many of these 
respondents saw some benefits in doing so. This study confirms the significant role of nurseries in gardeners' plant choice, and raises questions about the significance of dumping garden waste.

Key words: dumping garden waste; nursery; plant purchase; weed management

\section{Acronyms}

\begin{tabular}{|l|l|}
\hline IRSAD & Index of Relative Socio-Economic Advantage and Disadvantage \\
\hline LGA & Local Government Area \\
\hline NSW & New South Wales \\
\hline OR & Odds Ratio \\
\hline SD & Standard Deviation \\
\hline
\end{tabular}




\section{Introduction}

In Australia, environmental weeds, defined as 'plants that invade natural ecosystems and are considered to be a serious threat to natural conservation' (Williams \& West 2000, p. 425), have been widely reported to be capable of leading to significantly reduced abundance and diversity of native species (Stenhouse 2001; Yurkonis et al. 2005). Among exotic plant species that naturalised in Australia from 1970 to 1995, about two thirds were imported by the ornamental horticulture industry (Groves et al. 2005). This mirrors global processes in which the majority of significant environmental weeds are ornamental and garden plants outside their natural geographical range (Tyrrell 2007; Virtue et al. 2008). Such plant mobility is not only a matter of history. Growing national and international commercial trade in plants is implicated in the ongoing distribution of actual and potential environmental weeds (Drew et al. 2010) in Australia (Groves et al. 2005), New Zealand (Howell 2008), USA (Coats et al. 2011) and Europe (Heywood 2011).

One important reason for the ongoing importation and sale of potentially invasive garden plants in Australia is poorly organised legislative control and the lack of a national response (Mason et al. 2005; see Drew et al. 2010 for the USA). Although 
there is a strong argument for a legislative system to restrict the trade of any plants with invasive characteristics at a national level (Roush et al. 1999; Moss \& Walmsley 2005), the administrative difficulty and expenditure would be considerable (Timms 2006; Gagliardi \& Brand 2007), and it may not be welcomed by the public. For example, plant bans and taxation are unpopular methods for weed management and may cause a backlash from the public (Dempster 2002; Gagliardi \& Brand 2007). Thus, state and local environmental controls and initiatives, and community education programs which rely on a clear understanding of the involvement of local residents in the flow of potentially invasive garden plants, remain key elements in weed management.

Figure 1 shows the main pathway by which exotic garden plants spread into the natural environment with the help of human activities. After being imported and distributed through the nursery and horticultural industry, exotic plants are bought by gardeners and planted in domestic gardens. Subsequently, these plants may move across garden boundaries into neighbouring native vegetation (Zagorski et al. 2004; Groves et al. 2005). This study aims to clarify two key steps in the pathway, that is, from market to consumer (residents' procurement of garden plants), and from garden to the natural environment (via residents' garden-related behaviour). This aim was realised by 
drawing on a mail survey of householders whose property has at least one boundary adjacent to native vegetation designated as 'Natural Area' under the NSW Local Government Act 1993 in the Wollongong local government area (LGA), Australia. The two objectives of this study were to investigate: 1 . several key aspects of plant purchasing decisions by gardeners, for example, plant sources and criteria used in choosing garden plants; and 2. selected gardener behaviour both in their garden and in neighbouring reserves. A literature review is presented in the following subsection.

\section{Gardeners, nurseries and garden escapees}

Demand from gardeners remains a major contributor to the nature of plants imported and developed for Australian markets (Fig. 1), and invasive garden plants have not been recognised as a problem by many Australians (Blood \& Slattery 1996; Head \& Muir 2004). Gardeners do not necessarily prioritise nativeness or environmental issues such as potential invasiveness of garden plants when buying plants (Timms 2006; Qvenild et al. 2014). For Australian gardeners, more important plant attributes are aesthetic characteristics (Timms 2006; Head \& Muir 2007), the extent to which plants enhance the beauty of gardens (Dignam et al. 2003), their suitability for garden style and available space (van den Berg \& van Winsum-Westra 2010; Doody et al. 2014), and 
their care and watering requirements (Horticultural Research and Development Corporation 1991; Hitchings 2007; Qvenild et al. 2014). The aesthetic characteristics of garden plants are especially valued, particularly in relation to the psychological needs of gardeners (van den Berg \& van Winsum-Westra 2010). For example, Kirkpatrick et al. (2012) reported that $84 \%$ of respondents cited 'planting for beauty' as a reason for planting garden trees. In general, Australian gardeners have been found to find exotic garden plants more attractive than native plants (Timms 2006). It is such preferences that lead nursery businesses to search for and stock exotic plant species. This suggests the need for environmental initiatives that provide guidance about choosing garden plants to take the aesthetic preferences of gardeners into consideration when presenting alternatives to exotic plants.

Members of the public tend to assume that environmental weeds are not available for sale, and therefore plants on the market are not actual or potential weeds (Blood \& Slattery 1996). However, in Australia, nurseries, as a key source of both garden plants and gardening advice (Blood \& Slattery 1996; Dempster 2002; Dignam et al. 2003), may not actively cooperate with weed-control initiatives and weed authorities, and may not provide specific marketing for native or non-invasive plants. According to Moss and 
Walmsley (2005), one reason why nursery industry members have reacted negatively to any restriction on sales of potentially invasive garden plants was that there are other 'big players', such as Woolworths and Bunnings, who are not industry members and free from agreed restrictions. Thus, nursery industry members are potentially disadvantaged in the market. This suggests any initiatives that try to restrict the sale of potentially invasive garden plants should be applied to the whole garden plant market by regulation rather than relying on voluntary codes used only by nurseries.

While nursery industry bodies have developed voluntary codes of behaviour regarding invasive plants (Nursery and Garden Industry Australia 2012), it is not clear to what extent nurseries themselves provide advice that will encourage plant choices that minimise the risks associated with invasive plants. In this study, we examine respondents' views regarding plant origin information (that is, whether introduced from abroad, native to Australia or local to the Illawarra) provided by retailers. This origin information can be instructive for consumers in a market with invasive plants available for sale (Groves et al. 2005). To the authors' knowledge, people's plant choices and the extent to which plant origin information is available in retailers have not been comprehensively studied in Australia. 
After plants are brought from nurseries to domestic gardens, they may spread into the neighbouring environment (Zagorski et al. 2004; Groves et al. 2005) by natural means, such as birds, wind, and storm water (Kern 2006; Timmins et al. 2010), or human activities, such as dumping garden waste and via tracks and people walking through nearby reserves (Sullivan et al. 2005; Timmins et al. 2010). The abundance of weeds in reserves is related to proximity, size, age and density of nearby human settlements, and species richness of gardens within them (Timmins \& Williams 1991; Sullivan et al. 2004). There are more exotic plant species in urban areas than in rural and natural areas, because of favourable conditions (high light and high disturbance) for these species, and roads connecting cities to other settlements (Sullivan et al. 2005).

Hence, garden waste dumping in urban natural areas by gardeners has attracted much attention from weed authorities and relevant education programs as a likely source of environmental weeds in native vegetation (Batianoff \& Franks 1998). Dumping has been anecdotally reported to relate to weed establishment and has been broadly observed by local weed officers and previous studies (Sullivan et al. 2009). Garden waste is likely to increase the spread of weed species that would not disperse far by 
natural means, and closer dumping to reserves would reduce the time for a weed to reach there. Examples of such species include Broom (Cytisus scoparius) and Wandering Jew (Tradescantia fluminensis) (Timmins et al. 2010). Although the potential role of dumping garden waste in weed dispersal has been demonstrated, and limiting weed dispersal by raising public awareness of responsible gardening has been recommended, questions about how frequently people perform this behaviour, and why, are little explored, as are garden waste disposal methods in general.

\section{Methods and study area}

This paper draws on work from a broader survey project about weed management and garden-related behaviour. For this project, self-administered questionnaires were sent to 2000 of 7448 households adjacent to Natural Areas in the Wollongong LGA in 2013. One adult responsible for gardening decisions from each household was invited to complete the questionnaire.

The Wollongong LGA, which had a population of 288,101 in 2011, is located in the Illawarra Region of New South Wales (Department of Infrastructure and Transport 2012). The Illawarra region has various landscapes, including temperate rainforest, open 
grassland, estuaries, lakes and coastal streams (Southern Rivers Catchment Management Authority 2009), with over 200 naturalised weed species (Wollongong City Council 2009). This region is also situated in the Sydney Basin Bioregion, one of the most species-rich bioregions in Australia (NSW National Parks and Wildlife Service 2003). In the Illawarra, suburban and other settlement is intertwined with fragmented native ecosystems as a result of rugged terrain (Head \& Muir 2006), with $9.6 \%$ of domestic houses within $130 \mathrm{~m}$ of natural reserves (Chen 2005), making this area suitable for studying the interaction between domestic spaces and bushland.

A stratified and cluster sampling strategy was employed. We listed all Wollongong suburbs and their Index of Relative Socio-Economic Advantage and Disadvantage (IRSAD) (Australian Bureau of Statistics 2013). The suburbs are ranked into ten ordinal categories from the most disadvantaged to the most advantaged (Pink 2011) according to their IRSAD values. We sent 2000 questionnaires to suburbs across the IRSAD spectrum to gain responses from various socio-economic groups. We did also consider sending more questionnaires to suburbs of low socio-economic status with low IRSAD ranks, because mail surveys to populations with a low economic status usually achieve low response rates (Mammen \& Sano 2012). However, we abandoned this idea, because 
sample size determined by response rate must be based on previous studies (Barlett et al. 2001), and we had no such data.

Resource limitations precluded follow-up delivery of the survey. However, we delivered a follow-up letter thanking those who had completed the survey and requesting completion from those who had not. In case householders no longer had the survey, we again provided the link to an online version of the survey. Three hundred and eightytwo questionnaires were sent back (response rate $=19.1 \%$ ).

In the questionnaire, people were firstly asked to indicate: what are your sources of new garden plants (plant source) and information about choosing garden plants (plant information source), and which issues do you think about before you choose new garden plants (plant criterion). Multiple responses to these questions were allowed.

Additionally, respondents rated two ordinal items from strongly disagree (1) to strongly agree (5). These items were: 'at places where garden plants are for sale, there is sufficient information about the origin of plants (introduced from abroad, native in Australia or local in Illawarra)' (perceived origin information; Mean $=2.60, S D=1.30$ ) 
and 'I find the range of garden plants offered by retailers such as nurseries limits my ability to buy the plant I want' (perceived plant limitation; Mean $=3.05, S D=1.19$ ). The two variables indicate whether consumers are fully informed of the origin of plants to be sold, and have enough opportunities to purchase proper plants.

Ordinal regression was conducted to determine which source of garden plants significantly predicted respondents' perceived origin information. Plant source was divided into four dichotomous variables (nursery, botanic garden/Greenplan, supermarkets and grocers, and other) for simplification. Greenplan is an environmental initiative run by Wollongong City Council, and is located within the Wollongong botanic gardens. It provides Wollongong ratepayers with a wide range of local plants at a low cost, but only opens once per month. Each dichotomous variable had two values: 1 (yes) and 0 (no), with 1 indicating that this respondent had obtained garden plants from this source, and 0 indicating they had not.

Finally, respondents indicated how often they performed the five given garden-related behaviours (gardening, weeding within the garden, and three behaviours - weeding, bush restoration, and leaving organic materials, such as lawn clippings - in 
neighbouring reserves). They are behaviours that gardeners would perform to generate or transfer plant residues, especially weed residues, across garden boundaries. Spearman's rank-order correlation was conducted to explore relationships among these behaviours in order to indicate which behaviours generate the organic materials left in reserves, and where they are generated (within or outside garden). We also asked respondents to indicate their reasons for leaving organic materials in reserves (multiple responses were allowed), and which weed species they thought most significant in their garden or neighbouring reserves.

\section{Results and discussion}

There were four key results from this study. Firstly, most respondents obtained garden plants and relevant information from nurseries but perceived that there was insufficient plant origin information to help them make choices. Secondly, 'suitability to the conditions of my garden' and 'appearance' were the most common criteria for choosing garden plants. Thirdly, leaving organic materials in neighbouring reserve(s) was not commonly performed by most respondents. Only $6.6 \%$ of those who obtained plants from commercial garden plant retailers, and never performed bush restoration and weeding in neighbouring reserve(s), left organic materials at least once per month. 
Finally, leaving organic materials is significantly correlated with bush restoration and weeding in neighbouring reserve(s), but has a weak correlation with gardening, indicating some organic materials left in reserves are probably not generated in gardens but in reserves themselves. If this is correct, it is likely that practices of leaving organic waste reserves is not simply a matter of dumping garden waste but may comprise a more mixed set of activities and materials arising from gardeners' activities and relationships across garden and reserve boundaries.

\section{Plant procurement}

Nearly $80 \%$ of respondents reported 'nurseries' as their source of garden plants (Fig. 2).

Nurseries are frequently highlighted as sources by previous studies (Groves et al. 2005;

Moss \& Walmsley 2005; Timms 2006). 'Supermarkets and grocers' was the second most widely cited plant source (38.4\%). It is unsurprising that they are considered to be potential competitors for nurseries, and they are partly responsible for the failure of members of the nursery industry to give up the sale of potentially invasive garden plants with commercial value (Moss \& Walmsley 2005). 'Friends and relatives' accounted for a similar proportion of respondents compared to 'supermarkets and grocers'. It will be hard to directly influence, by policy and environmental initiatives, the flow of garden 
plants between people who are not involved in commercial plant retailing, underscoring the importance of raising the public's environmental awareness and self-regulation. Further, 'botanic garden/Greenplan', the council nursery and initiative, was a source for a relatively small proportion (23.5\%) of respondents.

'Nurseries', reported by $62.3 \%$ of respondents, were also the most common source of respondents' information about choosing garden plants (Fig. 3). This is consistent with previous findings (Blood \& Slattery 1996; Roush et al. 1999; Dempster 2002). Nearly $60 \%$ of respondents reported they have received plant information from 'friends and families', which is almost as significant as nurseries. 'Environmental initiatives (brochures and workshops)' (21\%) and 'formal education' (6.1\%) were among the least important plant information sources. The relatively minor role of initiatives in providing garden plants and information implies two possibilities. First, these initiatives may not be popular or accessible to most respondents. Even if residents who live adjacent to bushland generally do not want to grow invasive plants, they simply do not have enough information to guide their behaviour. Second, most respondents do not care about the weed issue and have no interest in contributing to natural area management, thus they simply ignore weed-control initiatives. If the first possibility is correct, it would be 
necessary for relevant authorities and environmental initiatives to question the effectiveness of the means by which environmental information about weed invasion is currently disseminated, and to develop strategies to remove the obstacles that inhibit the public from obtaining environmental information. If the second possibility is correct, there seem to be other factors that exert a more powerful influence on respondents' plant choice than environmental information. It is important to identify the underlying factors that contribute to, or inhibit, residents’ environmental behaviour.

For perceived plant limitation, $44.7 \%$ of respondents reported that the plants offered by retailers limited their ability to choose what they wanted, while $40 \%$ disagreed with that, and the rest were unsure. For perceived origin information, 52.6\% of respondents disagreed that retailers provided sufficient plant origin information, 29.3\% agreed with that, and $18.1 \%$ ticked unsure. This indicates that consumers would benefit from enhanced plant origin information in garden plant outlets.

For the ordinal regression to examine the relationship between plant source and perceived origin information, we firstly examined its assumptions (all statistics in this model were generated by statistical package SPSS 17). The sample size (369) was 
deemed adequate, and $13.8 \%$ of the total cells (dependent variable levels by combinations of predictor variable values) had zero frequencies. In terms of multicollinearity, the tolerance values were all larger than 0.1 , and the Variance Inflation Factors were all less than 10, showing collinearity was not a serious issue (Menard 1995). The test of parallel lines $(p=.316)$ indicated the assumption of proportional odds was not violated. The Nagelkerke pseudo $R^{2}$ (Table 1) for the regression analysis was $4.7 \%$ (this statistic approximates the amount of variance explained). Although it was relatively low, indicating that a model only containing these explanatory variables may not be a good predictor of the dependent variable, the results (Table 1) for 'nursery' ( $p<.01)$, and 'supermarkets and grocers' $(p<.05)$ were statistically significant. Both of their ORs’95\% confidence intervals were lower than 1 (the value of zero effect), indicating a significantly lower likelihood of rating a higher score in perceived origin information.

Respondents who reported having obtained garden plants from nurseries $(\mathrm{OR}=0.494)$, supermarkets and grocers $(\mathrm{OR}=0.566)$ were only around half as likely to rate higher in perceived origin information as those who did not choose these sources. Respondents who reported having obtained garden plants from botanic garden/Greenplan and other 
sources did not have a significant difference in perceived origin information from those who did not. The two choices' 95\% confidence intervals for OR both contained 1 (the value of zero effect), indicating at this level of confidence there is no or weak association between obtaining garden plants from these sources and respondents' perceived origin information.

The results suggest that, compared with other plant sources, nurseries, supermarkets and grocers as the dominant garden plant retailers may not actively inform consumers of the origin of plants to be sold. Previous studies reported that nurseries promote new exotic plants to generate business (Groves et al. 2005; Timms 2006; Drew et al. 2010), but supermarkets and other grocers are not widely mentioned. If nurseries and supermarkets in fact provide insufficient origin information, the reason could be that this origin information may reduce consumers’ willingness to purchase certain exotic plants.

The most important issues respondents thought about before choosing garden plants (Fig. 4) are 'its suitability to the condition of my garden' and 'its appearance', reported by $84.3 \%$ and $76.9 \%$ of respondents respectively. This is consistent with previous research reporting that plant and garden appearance are central to plant purchasing 
decisions (Horticultural Research and Development Corporation 1991; van den Berg \& van Winsum-Westra 2010). 'Cost', 'amount of maintenance' and 'potential habitat value for animals' were also commonly considered and all reported by about $60 \%$ of respondents. Two environment-related properties of plants ('potential to become a weed' and 'to spread out') were among the least important issues, but still more than one third of respondents considered them.

\section{Garden-related behaviours}

The frequency of each garden-related behaviour is shown in Table 2. The answer to each question asking the frequency of each behaviour was coded from 0 (never) to 5 (the other end of the scale). Table 3 presents means and standard deviations.

Most respondents gardened very frequently (Table 2), with more than 60\% gardening every day or at least once a week. According to Head and Muir (2007, p. 62), gardening is the second most popular outdoor activity in Australia. The benefits and motivations associated with gardening have been widely reported (Horticultural Research and Development Corporation 1991; Kiesling \& Manning 2010). Most respondents did weeding in their gardens at a moderate frequency, with more than 50\% weeding at least 
every fortnight, reflecting how often people have to weed to keep unwanted garden plants under control. The weed species of most significance (reported by $44.2 \%$ of respondents) at the garden/bushland interface were Lantana (Lantana camara) and Wandering Jew (Tradescantia fluminensis). Both species were introduced as ornamental plants.

All of the behaviours in neighbouring reserve(s) were seldom performed by most respondents, with more than half never weeding, more than two thirds never doing bush restoration, and more than three fourths never leaving organic materials in neighbouring reserve(s). There are two possible reasons for the low frequency of weeding and bush restoration in neighbouring reserve(s). First, the vegetation in reserves may not be perceived as 'neat' and 'relaxing', and people generally do not take care of this kind of environment (Nassauer 1997; Beck et al. 2002; Clayton 2007). Second, the public may have little willingness to take care of or protect bushland in reserves that are threatened by weed invasion, seeing these areas as council responsibility (Timms 2006; Head \& Muir 2007). 
The results about leaving organic materials in neighbouring reserve(s) raise questions about the significance of this issue. Dumping garden waste is generally thought to assist in the spread of invasive garden plants (Sullivan et al. 2005; Timmins et al. 2010). It is hard to conclude whether dumping garden waste manually by gardeners who live adjacent to bushland is a serious issue in our study area. Only $11.6 \%$ of respondents left organic materials in neighbouring reserve(s) at least once per month. Among respondents who obtained garden plants from nurseries, supermarkets or grocers, and did not perform bush restoration and weeding in neighbouring reserve(s), only $6.6 \%$ left organic materials at least once per month. Further, we do not know how much waste is dumped, nor anything about its composition. Nonetheless, the cumulative effect of continuous dumping at this rate may be significant. Although most respondents reported they have never left organic materials, the number of those respondents may be overestimated, because 'never leaving organic materials' may be treated as a socially desirable choice.

For respondents' reasons for leaving organic materials $(N=76)$, 'I use it as compost or mulch' (53.9\%) and 'it is good for the environment' (31.6\%) are the most common, showing a majority of those respondents see some benefits to doing so. This is probably 
a sign of misunderstanding the potential environmental impact of domestic materials left in reserves. Other relatively common reasons included 'inadequate bin capacity' (27.6\%) and 'it is convenient' (23.7\%), and 3.9\% of respondents chose 'other'.

The correlations (Table 3) show that the two behaviours within the garden are significantly correlated with each other. The three behaviours in neighbouring reserve(s) are also significantly correlated with each other, showing they may often be performed simultaneously. Leaving organic materials in neighbouring reserve(s) has little correlation with behaviours within the garden. It is possible that some materials left in neighbouring reserve(s) by respondents are not generated by behaviours within the garden, but by bush restoration and weeding in neighbouring reserve(s). It is important for weed authorities to suggest to those people who weed or restore bushland in reserves that it is necessary to remove or eradicate the weed residues from reserves, because they may regrow.

\section{Conclusion}

In contrast to much previous research that tends to focus on either industry behaviour or structure, gardener preferences, or ecological perspectives on plant mobility, our 
research highlights interconnections between these areas. While we focus on gardener behaviour and preferences, our results show that decisions about plants are intertwined with where and how plants are sold. Further, our findings highlight a range of informal and everyday activities and beliefs, such as plant exchange and garden waste disposal that are under-researched with respect to social aspects of plant mobility.

Factors that influence gardeners' plant decision making, and how garden plants spread into bushland with the help of human activities, are crucial in formulating effective weed management strategies. This study firstly indicates the important role of nurseries and the relatively minor role of environmental initiatives in providing garden plants and relevant information. Concurring with studies in other countries, particularly the USA (Drew et al. 2010), self-regulation of horticulture industry is an important means to restrict the trade of invasive garden plants, but its effectiveness in the long term is questionable. The diversity and fragmentation of plant retailing likely further mitigates against such effectiveness. Additionally, the reported deficiency of plant origin information from nurseries implies that consumers lack necessary environmental information to guide their plant purchasing decisions. Environmental suitability is among the least important factors that respondents consider when choosing garden plants. In our study, as elsewhere, gardeners prioritise factors such as appearance in 
choosing plants. It seems that the market and gardeners conjunctly create the conditions for invasive plants to be widely distributed. In the absence of strong industry regulation and codes of practice, and with weak influence of environmental initiatives, it is likely that the problem of garden escapees will persist. Future research can help to further quantify the plant flow from the market to gardeners, for example, how many and how often garden plants are purchased, and the proportion of native or exotic garden plants.

Moreover, existing research suggests that dumping garden waste is an important means for new and existing garden plants to be transferred to bushland. However, it is hard to draw definitive conclusions on the basis of our survey results alone. Future socioecological research would help to clarify the amount, composition, and capacity of organic materials left in reserves to transfer garden plants to them, and the extent to which this practice is as significant in weed dispersal as commonly assumed. Further, such work could investigate the extent to which this practice introduces plants, which are new to retail markets, to reserves as compared to being a means of redistributing existing invasive plants. Finally, the fact that many of those who left organic materials see it as beneficial to the environment or as useful mulch or compost suggests that a 
significant issue is beliefs about the inherent value of organic matter of any type and its role in concepts and practices of looking after urban nature. 


\section{REFERENCES}

Australian Bureau of Statistics (2013) 2033.0.55.001 - Census of population and housing: Socio-Economic Indexes for Areas (SEIFA), Australia, 2011. Catalogue Number 2033.0.55.001, Australian Bureau of Statistics, Canberra.

Barlett, J.E., Kotrlik, J.W. \& Higgins, C.C. (2001) Organizational research: determining appropriate sample size in survey research. Information Technology, Learning, and Performance Journal 19, 43-50.

Batianoff, G.N. \& Franks, A.J. (1998) Environmental weed invasions on south-east Queensland foredunes. Proceedings of the Royal Society of Queensland 107, 15-34.

Beck, T.B., Heimlich, J.E. \& Quigley, M.F. (2002) Gardeners' perceptions of the aesthetics, manageability, and sustainability of residential landscapes. Applied Environmental Education and Communication 1, 163-172. 
van den Berg, A.E. \& van Winsum-Westra, M. (2010) Manicured, romantic, or wild? The relation between need for structure and preferences for garden styles. Urban Forestry \& Urban Greening 9, 179-186.

Blood, K. \& Slattery, D. (1996) “I’ve got angled onion in my garden and I reckon it’s OK!” Environmental weeds and community education. In: Shepherd, R.C.H. (ed.) 11th Australian Weeds Conference Proceedings: Where in the World Is Weed Science Going? The Weed Science Society of Victoria, Victoria, pp. 520-523.

Chen, K. (2005) Counting bushfire-prone addresses in the Greater Sydney Region. Proceedings of the Symposium on Planning for Natural Hazards - How Can We Mitigate the Impacts? University of Wollongong, 2-5 February 2005.

Clayton, S. (2007) Domesticated nature: motivations for gardening and perceptions of environmental impact. Journal of Environmental Psychology 27, 215-224. 
Coats, V.C., Stack, L.B. \& Rumpho, M.E. (2011) Maine nursery and landscape industry perspectives on invasive plant issues. Invasive Plant Science and Management 4, 378389.

Dempster, H.E. (2002) Nursery and garden industry of Australia: garden escapees that are serious environmental weeds. In: Jacob, H.S., Dodd, J. \& Moore, J.H. (eds) 13th Australian Weeds Conference Proceedings: Weeds 'Threats Now and Forever'. Plant Protection Society of WA, Western Australia, pp. 27-32.

Department of Infrastructure and Transport (2012) State of Australian cities 2012 [WWW document]. URL http://www.infrastructure.gov.au/infrastructure/mcu/soac/files/factsheets_2012/Wollong ong_Factsheet_FA.pdf [accessed on 11 October 2013].

Dignam, M. \& associates (2003) Nursery and Garden Industry Consumer Research. Horticulture Australia Ltd, Sydney. 
Doody, B.J., Perkins, H.C., Sullivan, J.J., Meurk, C.D. \& Stewart, G.H. (2014) Performing weeds: gardening, plant agencies and urban plant conservation. Geoforum $56,124-136$.

Drew, J., Anderson, N. \& Andow, D. (2010) Conundrums of a complex vector for invasive species control: a detailed examination of the horticultural industry. Biological Invasions 12, 2837-2851.

Gagliardi, J.A. \& Brand, M.H. (2007) Connecticut nursery and landscape industry preferences for solutions to the sale and use of invasive plants. HortTechnology 17, 3945.

Groves, R.H., Boden, R. \& Lonsdale, W.M. (2005) Jumping the Garden Fence: Invasive Garden Plants in Australia and Their Environmental and Agricultural Impacts. CSIRO report prepared for WWF-Australia, WWF-Australia, Sydney.

Head, L. \& Muir, P. (2004) Nativeness, invasiveness, and nation in Australian plants. Geographical Review 94, 199-217. 
Head, L. \& Muir, P. (2006) Edges of connection: reconceptualising the human role in urban biogeography. Australian Geographer 37, 87-101.

Head, L. \& Muir, P. (2007) Backyard: Nature and Culture in Suburban Australia. University of Wollongong Press, Wollongong, New South Wales.

Heywood, V.H. (2011) The role of botanic gardens as resource and instruction centres in the face of global change. Biodiversity Conservation 20, 221-239.

Hitchings, R. (2007) Approaching life in the London garden centre: acquiring entities and providing products. Environment and Planning A 39, 242-259.

Horticultural Research and Development Corporation (1991) National Consumer and Retailer Study of Nursery Industry Opportunities 1991: A Marketing Research Report. Horticultural Research and Development Corporation, Canberra. 
Howell, C. (2008) Consolidated List of Environmental Weeds in New Zealand. DOC Research and Development Series 292, Department of Conservation, Wellington.

Kern, L. (2006) Long distance dispersal of environmental weeds: potential lessons for community education. Plant Protection Quarterly 21, 141-145.

Kiesling, F.M. \& Manning, C.M. (2010) How green is your thumb? Environmental gardening identity and ecological gardening practices. Journal of Environmental Psychology 30, 315-327.

Kirkpatrick, J.B., Davison, A. \& Daniels, G.D. (2012) Resident attitudes towards trees influence the planting and removal of different types of trees in eastern Australian cities. Landscape and Urban Planning 107, 147-158.

Mammen, S. \& Sano, Y. (2012) Gaining access to economically marginalized rural populations: lessons learned from nonprobability sampling. Rural Sociology 77, 462482. 
Mason, T.J., Lonsdale, W.M. \& French, K. (2005) Environmental weed control policy in Australia: current approaches, policy limitations and future directions. Pacific Conservation Biology 11, 233-245.

Menard, S. (1995) Applied Logistic Regression Analysis: Sage University Series on Quantitative Applications in the Social Sciences. Thousand Oaks, Sage, CA.

Moss, W. \& Walmsley, R. (2005) Controlling the Sale of Invasive Garden Plants: Why Voluntary Measures Alone Fail. WWF-Australia Discussion Paper, WWF-Australia, Sydney.

Nassauer, J.I. (1997) Cultural sustainability: aligning aesthetics and ecology. In: Nassauer, J.I. (ed.) Placing Nature: Culture and Landscape Ecology. Island Press, Washington, DC, pp. 65-83.

NSW National Parks and Wildlife Service (2003) The Bioregions of NSW: Their Biodiversity, Conservation and History. NSW National Parks and Wildlife Service, Hurstville. 
Nursery and Garden Industry Australia (2012) Reducing the Pest Risk - Industry’s Policy Position on Biosecurity and Quarantine. Nursery Papers Technical, Nursery and Garden Industry Australia.

Pink, B. (2011) Socio-Economic Indexes for Areas (SEIFA). Australian Bureau of Statistics, ACT.

Qvenild, M., Setten, G. \& Skår, M. (2014) Politicising plants: dwelling and invasive alien species in domestic gardens in Norway. Norsk Geografisk Tidsskrift - Norwegian Journal of Geography 68, 22-33.

Roush, R., Groves, R.H., Blood, K., Randall, R.P., Walton, C., Thorp, J. \& Csurhes, S. (1999) Garden Plants under the Spotlight: An Australia Strategy for Invasive Garden Plants. Draft released for public comment, CRC for Weed Management Systems and the Nursery Industry Association of Australia, Adelaide. 
Southern Rivers Catchment Management Authority (2009) Southern Rivers Catchment management authority homepage [WWW document]. URL http://www.southern.cma.nsw.gov.au [accessed on 12 December 2013].

Stenhouse, R. (2001) Management of urban remnant bushlands by the community and local government. Australian Journal of Environmental Management 8, 37-47.

Sullivan, J.J., Timmins, S.M. \& Williams, P.A. (2005) Movement of exotic plants into coastal native forests from gardens in northern New Zealand. New Zealand Journal of Ecology 29, 1-10.

Sullivan, J.J., Williams, P.A., Cameron, E.K. \& Timmins, S.M. (2004) People and time explain the distribution of naturalized plants in New Zealand. Weed Technology 18, $1330-1333$.

Sullivan, J.J., Williams, P.A., Timmins, S.M. \& Smale, M.C. (2009) Distribution and spread of environmental weeds along New Zealand roadsides. New Zealand Journal of Ecology 33, 190-204. 
Timmins, S.M. \& Williams, P.A. (1991) Weed numbers in New Zealand's forest and scrub reserves. New Zealand Journal of Ecology 15, 153-162.

Timmins, S.M., James, A., Stover, J. \& Plank, M. (2010) Is garden waste dumping really a problem? In: Zydenbos, S.M. (ed.) 17th Australasian Weeds Conference Papers \& Proceedings: New Frontiers in New Zealand, Together We Can Beat the Weeds. New Zealand Plant Protection Society, Christchurch Convention Centre, Christchurch, New Zealand, pp. 455-458.

Timms, P. (2006) Australia's Quarter Acre: The Story of the Ordinary Suburban Garden. Miegunyah Press, Australia.

Tyrrell, I. (2007) Environment, landscape and history: gardening in Australia. Australian Historical Studies 38, 339-347.

Virtue, J.G., Spencer, R.D., Weiss, J.E. \& Reichard, S.E. (2008) Australia’s botanic gardens weed risk assessment procedure. Plant Protection Quarterly 23, 166-178. 
Williams, J.A. \& West, C.J. (2000) Environmental weeds in Australia and New Zealand: issues and approaches to management. Austral Ecology 25, 425-444.

Wollongong City Council (2009) Weed management [WWW document]. URL http://www.wollongong.nsw.gov.au/services/sustainability/Pages/weedmanagement.asp x [accessed on 12 December 2013].

Yurkonis, K.A., Meiners, S.J. \& Wachholder, B.E. (2005) Invasion impacts diversity through altered community dynamics. Journal of Ecology 93, 1053-1061.

Zagorski, T., Kirkpatrick, J.B. \& Stratford, E. (2004) Gardens and the bush: gardeners’ attitudes, garden types and invasives. Australian Geographical Studies 42, 207-220. 


\section{Tables}

Table 1 Ordinal regression model for perceived origin information.

\begin{tabular}{|c|c|c|c|c|c|c|c|c|}
\hline \multirow{2}{*}{ Variable } & \multirow{2}{*}{ Parameter } & \multirow{2}{*}{$B$} & \multirow{2}{*}{$S E$} & \multirow{2}{*}{ OR } & \multicolumn{2}{|c|}{$\begin{array}{l}\text { 95\% confidence } \\
\text { interval of OR }\end{array}$} & \multirow{2}{*}{ Wald } & \multirow[b]{2}{*}{$p$} \\
\hline & & & & & $\begin{array}{c}\text { Lower } \\
\text { limit }\end{array}$ & $\begin{array}{l}\text { Upper } \\
\text { limit }\end{array}$ & & \\
\hline \multirow{4}{*}{ Threshold } & $\begin{array}{l}\text { Strongly } \\
\text { disagree }\end{array}$ & -1.894 & 0.278 & & & & 46.274 & $* * *$ \\
\hline & $\begin{array}{l}\text { Mildly } \\
\text { disagree }\end{array}$ & -0.690 & 0.263 & & & & 6.883 & $* *$ \\
\hline & Unsure & 0.117 & 0.261 & & & & 0.200 & 0.655 \\
\hline & $\begin{array}{l}\text { Mildly } \\
\text { agree }\end{array}$ & 1.617 & 0.291 & & & & 30.805 & $* * *$ \\
\hline Nursery & Yes & -0.705 & 0.226 & 0.494 & 0.317 & 0.770 & 9.705 & $* *$ \\
\hline $\begin{array}{l}\text { Botanic } \\
\text { garden/Greenplan }\end{array}$ & Yes & -0.209 & 0.225 & 0.811 & 0.522 & 1.260 & 0.864 & 0.353 \\
\hline $\begin{array}{l}\text { Supermarkets and } \\
\text { grocers }\end{array}$ & Yes & -0.570 & 0.228 & 0.566 & 0.362 & 0.884 & 6.265 & $*$ \\
\hline Other & Yes & 0.047 & 0.234 & 1.048 & 0.662 & 1.659 & 0.040 & 0.842 \\
\hline \multicolumn{2}{|l|}{ Nagelkerke pseudo $R^{2}$} & \multicolumn{7}{|l|}{$4.7 \%$} \\
\hline
\end{tabular}

Note: ${ }^{*} p<.05 ;{ }^{* *} p<.01 ;{ }^{* *} p<.001$. For all predictors, base $=$ no.

Table 2 Percentage of respondents by frequency in performing each garden-related

behaviour.

\begin{tabular}{|l|c|l|l|l|l|l|l|}
\hline \multicolumn{1}{|c|}{ Behaviour } & $N$ & \multicolumn{6}{|c|}{ Choice and percentage (\%) } \\
\hline \multirow{3}{*}{ Gardening } & 377 & $\begin{array}{l}\text { Every } \\
\text { day }\end{array}$ & $\begin{array}{l}\text { At least } \\
\text { once a } \\
\text { week }\end{array}$ & $\begin{array}{l}\text { At least } \\
\text { every } \\
\text { fortnight }\end{array}$ & $\begin{array}{l}\text { At least } \\
\text { once a } \\
\text { month }\end{array}$ & $\begin{array}{l}\text { Less than } \\
\text { once a } \\
\text { month }\end{array}$ & Never \\
\cline { 2 - 8 } & 19.9 & 41.7 & 16.3 & 14.2 & 7.1 & 0.8 \\
\hline & $\begin{array}{l}\text { At least } \\
\text { once a } \\
\text { week }\end{array}$ & $\begin{array}{l}\text { At least } \\
\text { every } \\
\text { fortnight }\end{array}$ & $\begin{array}{l}\text { At least } \\
\text { once a } \\
\text { month }\end{array}$ & $\begin{array}{l}\text { At least } \\
\text { every } \\
\text { three } \\
\text { months }\end{array}$ & $\begin{array}{l}\text { Less than } \\
\text { every } \\
\text { three } \\
\text { months }\end{array}$ & Never \\
\hline $\begin{array}{l}\text { Weeding within the } \\
\text { garden }\end{array}$ & 373 & 22.8 & 31.4 & 25.2 & 11.5 & 7.5 & 1.6 \\
\hline Leaving organic & 346 & 1.2 & 3.8 & 6.6 & 4.3 & 7.8 & 76.3 \\
\hline
\end{tabular}




\begin{tabular}{|l|l|l|l|l|l|l|l|}
\hline $\begin{array}{l}\text { materials (such as } \\
\text { lawn clippings) in } \\
\text { neighbouring } \\
\text { reserve(s) }\end{array}$ & 355 & 3.1 & 8.2 & 14.9 & 9.6 & 10.7 & 53.5 \\
\hline $\begin{array}{l}\text { Weeding in } \\
\text { neighbouring } \\
\text { reserve(s) }\end{array}$ & 339 & 0.9 & 4.1 & 7.7 & 7.1 & 10.9 & 69.3 \\
\hline $\begin{array}{l}\text { Bush restoration in } \\
\text { neighbouring } \\
\text { reserve(s) }\end{array}$ & & & & & & & \\
\hline
\end{tabular}

Table 3 Means, standard deviations and Spearman correlations for garden-related behaviours.

\begin{tabular}{|l|c|c|c|c|c|c|}
\hline & Mean & $S D$ & 1 & 2 & 3 & 4 \\
\hline 1. Gardening & 3.51 & 1.21 & & & & \\
\hline 2. Weeding within the garden & 3.46 & 1.26 & $0.514^{* *}$ & & & \\
\hline $\begin{array}{l}\text { 3. Leaving organic materials in } \\
\text { neighbouring reserve(s) }\end{array}$ & 0.57 & 1.19 & 0.082 & 0.1 & & \\
\hline 4. Weeding in neighbouring reserve(s) & 1.23 & 1.55 & $0.174^{* *}$ & $0.226^{* *}$ & $0.362^{* *}$ & \\
\hline $\begin{array}{l}\text { 5. Bush restoration in neighbouring } \\
\text { reserve(s) }\end{array}$ & 0.69 & 1.22 & $0.138^{*}$ & $0.156^{* *}$ & $0.276^{* *}$ & $0.696^{* *}$ \\
\hline
\end{tabular}

Note: ${ }^{*} p<.05 ; * * p<.01$. 


\section{Figure legends}

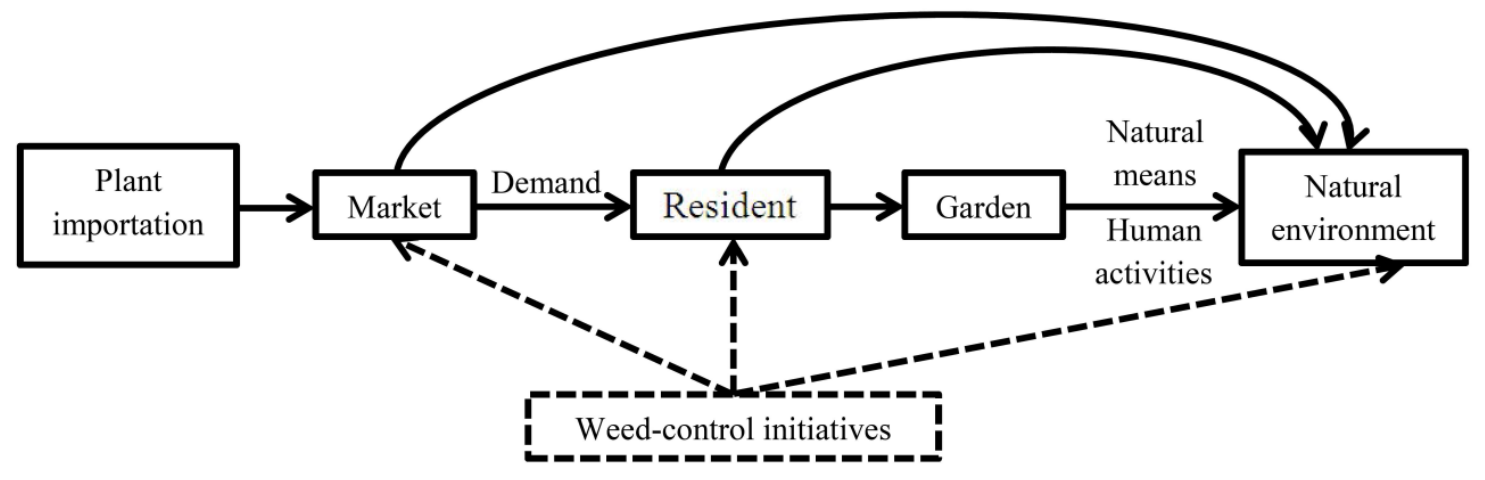

Fig. 1 Flow of exotic garden plants from the market to the natural environment.

Note: solid arrowed lines represent direction; dotted arrowed lines represent influence;

garden plants can also be circulated among residents.

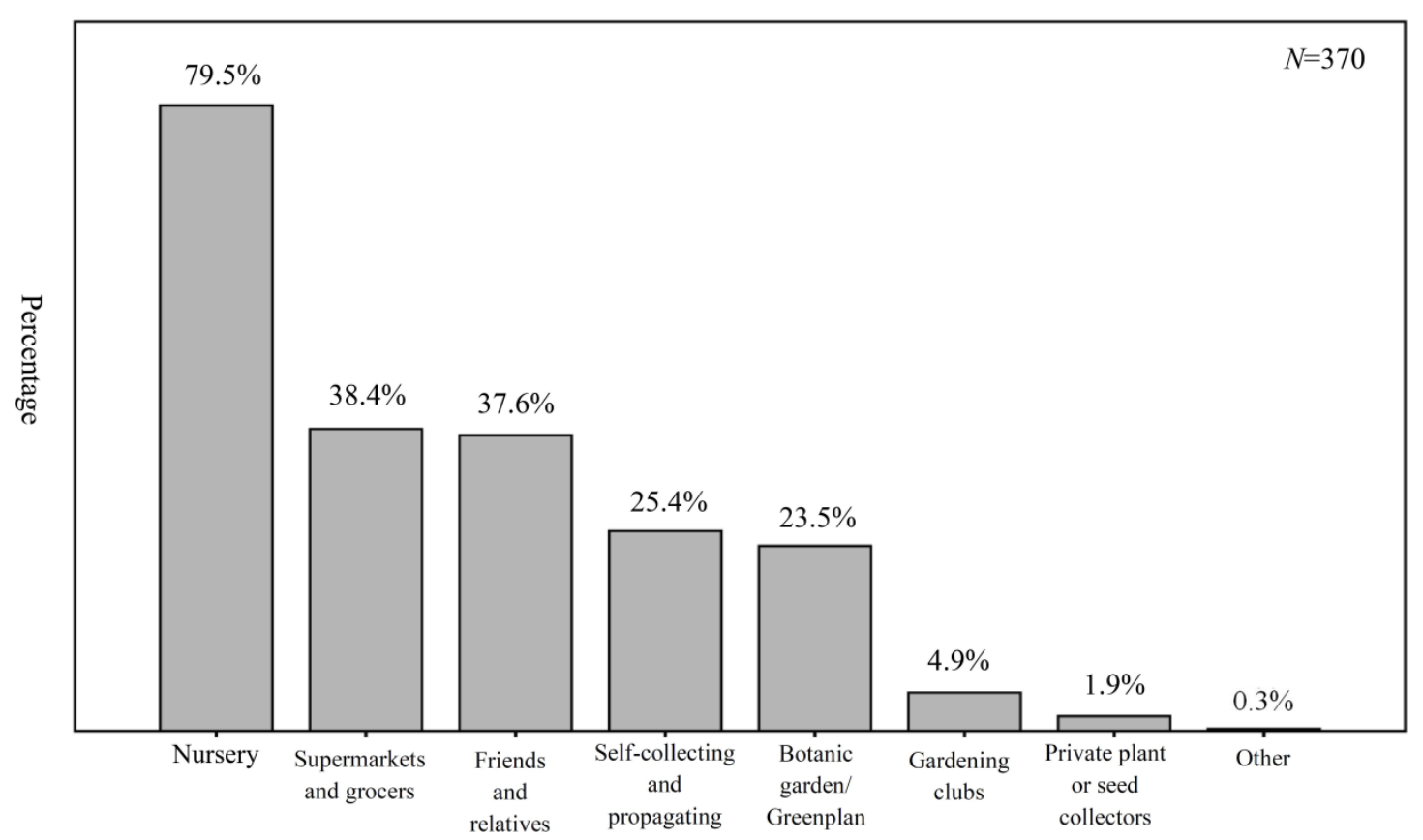

Fig. 2 Sources of garden plants for respondents.

Note: Greenplan is an environmental initiative run by Wollongong City Council, and is located within the Wollongong botanic gardens. 


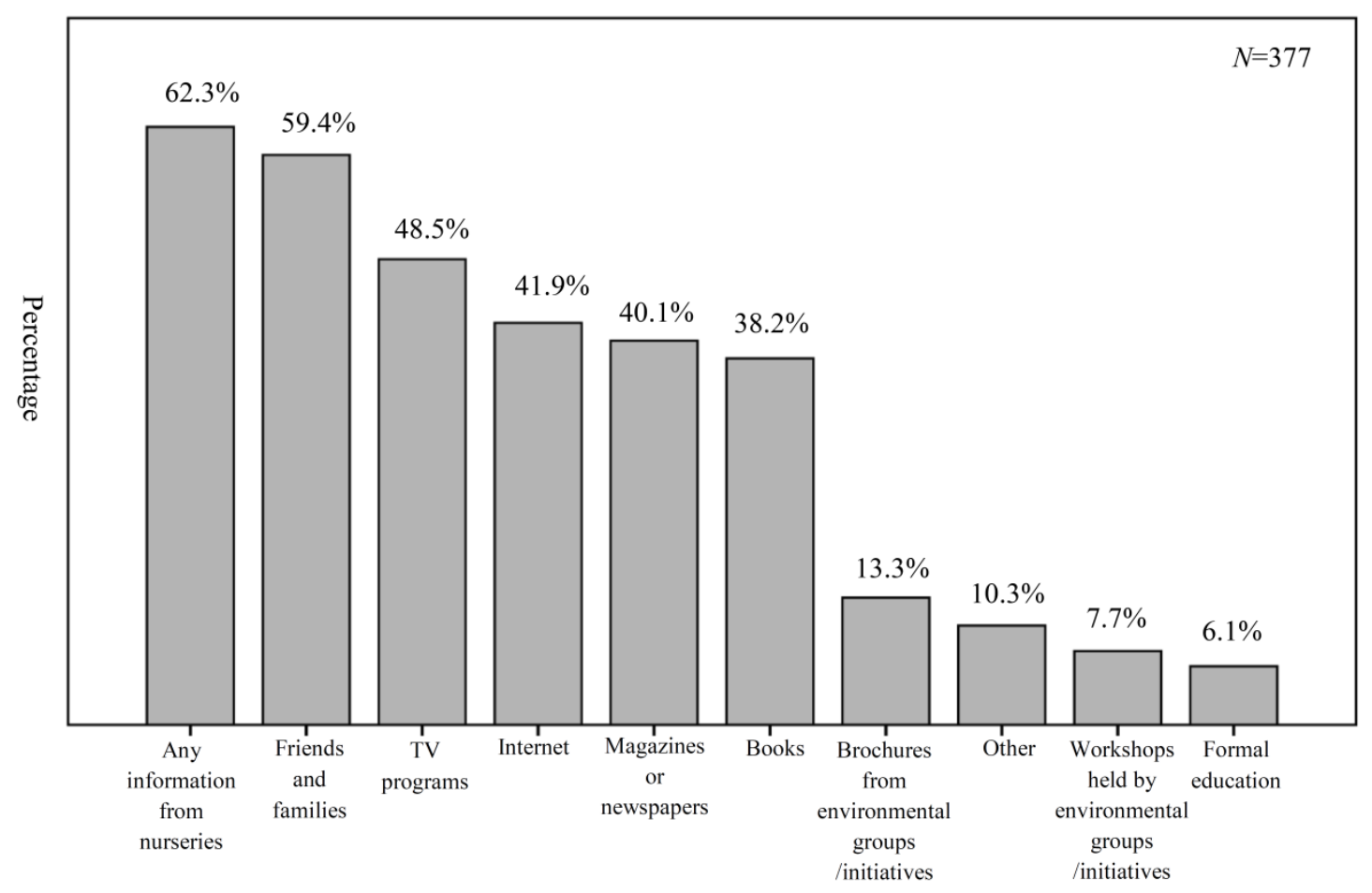

Fig. 3 Sources of information for respondents about choosing garden plants. 


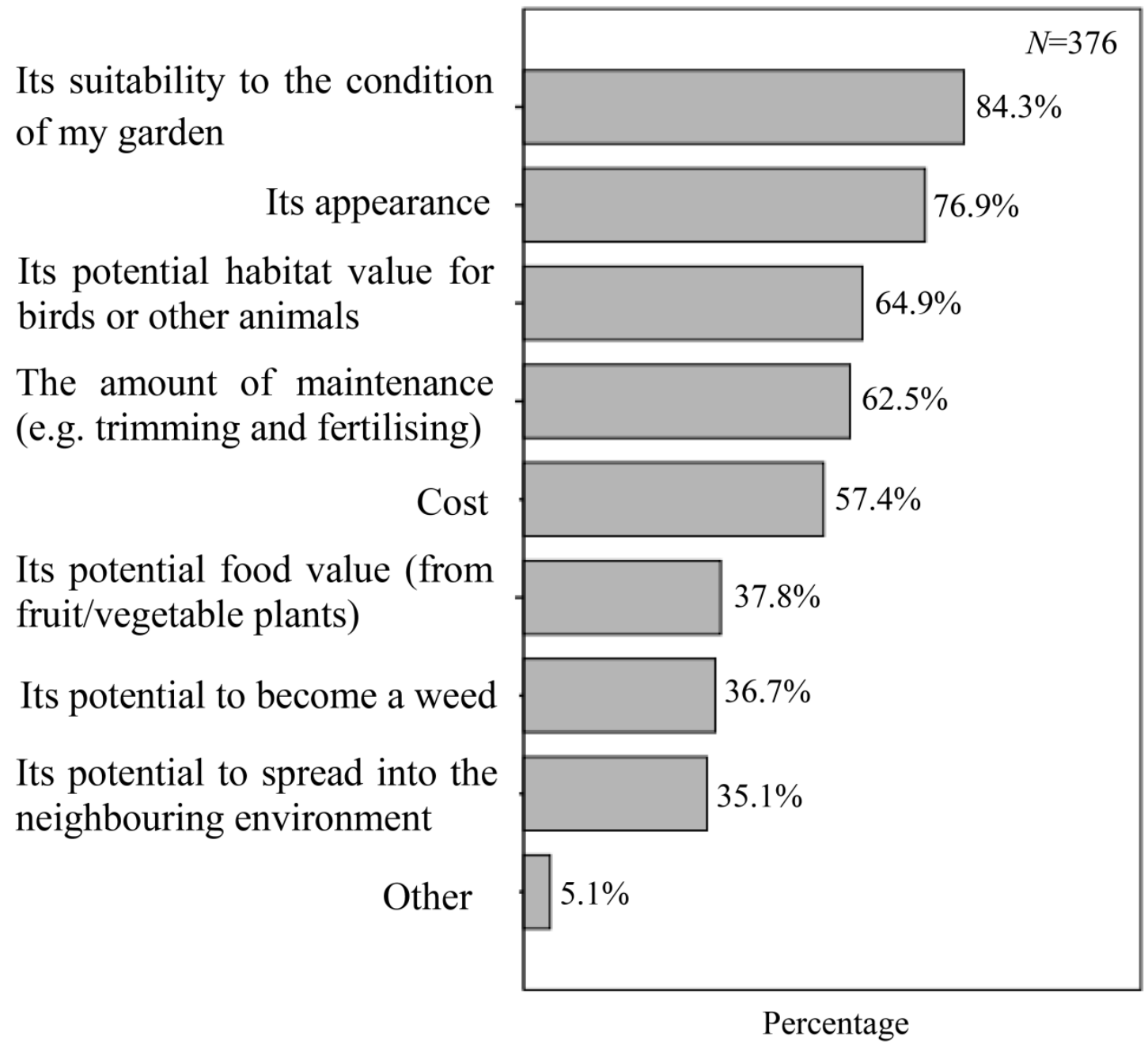

Fig. 4 Issues respondents thought about before choosing garden plants. 